\title{
АНАЛИЗ ВЛИЯНИЯ ПОСТПАНДЕМИЙНОГО КРИЗИСА НА РЫНОК ЖЕЛЕЗНОДОРОЖНЫХ ПЕРЕВОЗОК НЕФТЕНАЛИВНЫХ ГРУЗОВ
}

\section{(c) 2020 Житинев Петр Юрьевич}

магистрант

Петербургский государственный университет путей сообщения Императора Александра I ПГУПС, Россия, Санкт-Петербург

\section{(c) 2020 Журавлева Наталья Александровна}

доктор экономических наук, профессор

Петербургский государственный университет путей сообщения Императора Александра I ПГУПС, Россия, Санкт-Петербург

Коронавирус внес в мир так много неопределенности в отношении восстановления мировой экономики. Что означает ограничения ряда производств и социальное дистанцирование для различных отраслей, в том числе потребления углеводородов? Несомненно, одно: транспортная отрасль должна быть более устойчивой к последствиям любых будущих потрясений, поскольку она является одной из наиболее важных, системообразующих отраслей экономики. Целью данного исследования является оценка последствий нового экономического кризиса для рынка перевозок нефтеналивных грузов железнодорожным транспортом. Объектом исследования являются компании-операторы, обеспечивающие более $20 \%$ всех перевозок углеводородов и их производных. Предмет исследования составляют аналитические процедуры и методы обработки данных о состоянии и перспективах изменений рынка нефтеналивных грузов. Приведенные в статье результаты уточненного прогноза объемов перевозок различными видами транспорта, расчет индекса затрат на содержание подвижного состава, позволили обосновать вывод об уходе от конкурентной модели рынка перевозок нефтеналивных грузов к рынку олигополии, что существенно меняет бизнес-модели большинства грузовых операторов. Практическими результатами исследования являются рекомендации по оптимизации затрат компаний-операторов.

Ключевые слова: рынок перевозок нефтеналивных грузов; модель бизнеса грузовых операторов; оптимизация затрат.

Введение. Технико-экономические характеристики железнодорожного транспорта в совокупности с географическими особенностями территории Российской Федерации обеспечили ведущее положение железной дороги в транспортной системе государства.

Поэтапное развитие рынка грузовых железнодорожных перевозок стало катализатором повышения комплексности предоставляемых транспортно-логистических решений, диверсификации оказываемых сервисов и построения работы операторов подвижного состава на принципах оптимизации затрат и бизнес-моделей. Бизнес-модель организации - это совокупность ее процессов, с помощью которых она создает ценности (продукты, услуги), доставляет их на рынок и получает ответные ценности (деньги, технологии, репутацию и пр.) [5].

Непрогнозируемость кризисных явлений, таких как пандемия COVID-19, повлекшая за собой спад мировой экономики, формирует по- требность оценки влияния факторов посткризисной экономики на бизнес-модели транспортных организаций для выработки действенных механизмов их нивелирования. В условиях, когда в результате пандемии может быть прекращено транспортное сообщение внутри и между регионами на неопределенный срок, уровень платежеспособности потребителей транспортной услуги снизится по причине введения ограничительных мер и возникновения структурной безработицы, указанная оценка приобретает особую актуальность для транспортных организаций, специфика деятельности которых предполагает высокую долю постоянных затрат [1].

Объектом данного исследования является бизнес-модель организаций железнодорожного транспорта, а предметом - аналитические процедуры влияния глобальных трендов изменения постпандемийной экономики на операционную и деятельность транспортных организаций. 
Анализ рынка и тенденции его изменения.

Железнодорожный транспорт в Российской Федерации является крупнейшим по величине грузооборота (более 750,4 млрд. т-км или 45\%) и занимает второе место (после автомобильного) по объему перевозки, который по итогам 2019 года составил порядка 1280 млн. тонн или 17\% от общего объема всех перевезенных грузов в стране [9].

Структура перевозимых грузов по железной дороге в 2019 году существенным изменениям по сравнению с предыдущим годом не подверглась, наибольшую долю (порядка 70\%) формируют по-прежнему сырьевые грузы. Крупнейшая группа перевозимых грузов - каменный уголь, его перевозки оказывают наиболее существен- ное влияние на показатели работы железнодорожного транспорта.

Вторая по объему перевозок группа - нефтяные грузы. По итогам 2019 года перевезено 230,22 млн. тонн или 18\% от всей погрузки на железнодорожный транспорт.

Динамика объемов перевозки грузов железнодорожным транспортом за последние 6 лет условно стабильна: несмотря на незначительные спады в 2015 и 2019 годах, объем по итогам 2019 года вырос на 52 млн. тонн $(+4,3 \%)$ [9].

Однако, несмотря на условно стабильную динамику объема перевозок за рассматриваемый период произошло изменение структуры отгрузки. На протяжении всего анализируемого периода в общей структуре отгрузке сокраща-

\section{Структура перевозок грузов железнодорожным траспортом РФ в 2019г., \%}

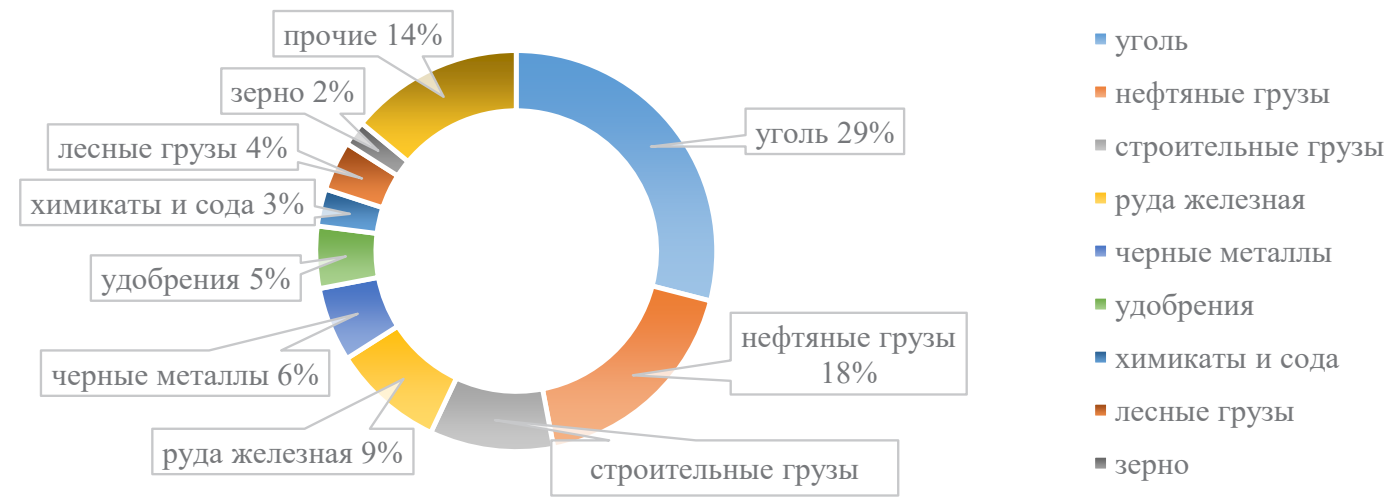

Рисунок 1. Структура перевозок грузов ж/д транспортом, \% [9]

Динамика объема перевозки ж/д транспортом за период 2014-2019гг., млн.тн

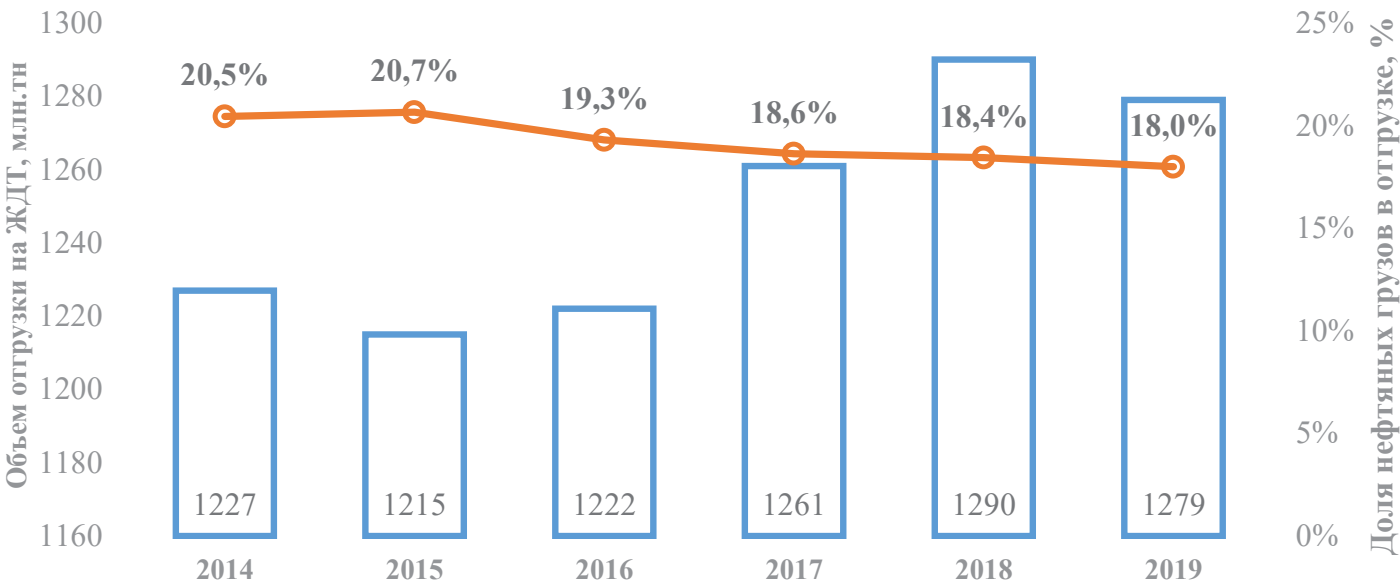

Рисунок 2. Динамика объема перевозки грузов ж/д транспортом [9] 
ется доля нефтяных грузов (сырая нефть и нефтепродукты). Так, по итогам 2019 года их доля сократилась на 2,5\% относительно уровня 2014 года, что в абсолютном выражении составило более 20 млн. тонн. Нефть и нефтепродукты относятся к III тарифному классу (согласно Тарифному руководству № 4 Прейскурант 10-01) - высокодоходным грузам, в связи с чем сокращение доли данной группы грузов в общей структуре отгрузке приводит к падению доходности железнодорожных перевозок в целом. [3]

\section{Прогноз объемов транспортировки не-} фтеналивных грузов железнодорожным транспортом.

Учитывая стратегическую значимость поставок нефти и нефтепродуктов для экономики и обороноспособности страны подробнее рассмотрим данные перевозки. На долю железнодорожного транспорта приходится более $80 \%$ всех перевозок нефтепродуктов в Российской Федерации. Основной дорогой, формирующей грузопотоки, является Западно - Сибирская железная дорога, в пределах которой сконцентрирован ряд крупнейших грузоотправителей Омский НПЗ, Ангарская НХК, Ачинский НПЗ, Антипинский НПЗ и др. В регионе производится и отгружается на железнодорожный транспорт более 30\% всех нефтепродуктов в РФ. Крупнейшей станцией погрузки является станция Комбинатская (Омский НПЗ), ежегодный объем погрузки на которой превышает 12 млн. тонн [2].
За период с 2014 по 2019 годы объем перевозки нефтеналивных грузов по железной дороге сократился с 257 млн. тонн до 230 млн. тонн (-27 млн. тонн или $-10,5 \%)$. Основным фактором снижения объема отгрузки нефтепродуктов по железной дороге является развитие трубопроводного транспорта. За период с 2014 по 2019 год ряд крупных нефтеперерабающих заводов (Волгорадский НПЗ, Самарская группа заводов, Киришский НПЗ) был подключен к системе магистральных нефтепродуктопроводов ПАО «Транснефть» [4].

По мере поэтапной реализации проекта «ЮГ» (проект строительства магистральных трубопроводов) наблюдается снижение доли железнодорожного транспорта в общей структуре отгрузки и соразмерный рост доли трубопроводного транспорта.

Несмотря на указанное снижение объемов отгрузки нефтепродуктов на железнодорожный транспорт, существенного изменения ситуации на рынке не прогнозируется, в т.ч. по следующим причинам:

- Основные проекты строительства нефтепродуктопроводов на завершающей стадии реализации;

- Увеличение глубины переработки на крупных НПЗ, которое в свою очередь повышает требования к сохранению качественных характеристик грузов, который в состоянии обеспечить только дифференцированный железнодорожный подвижной состав;

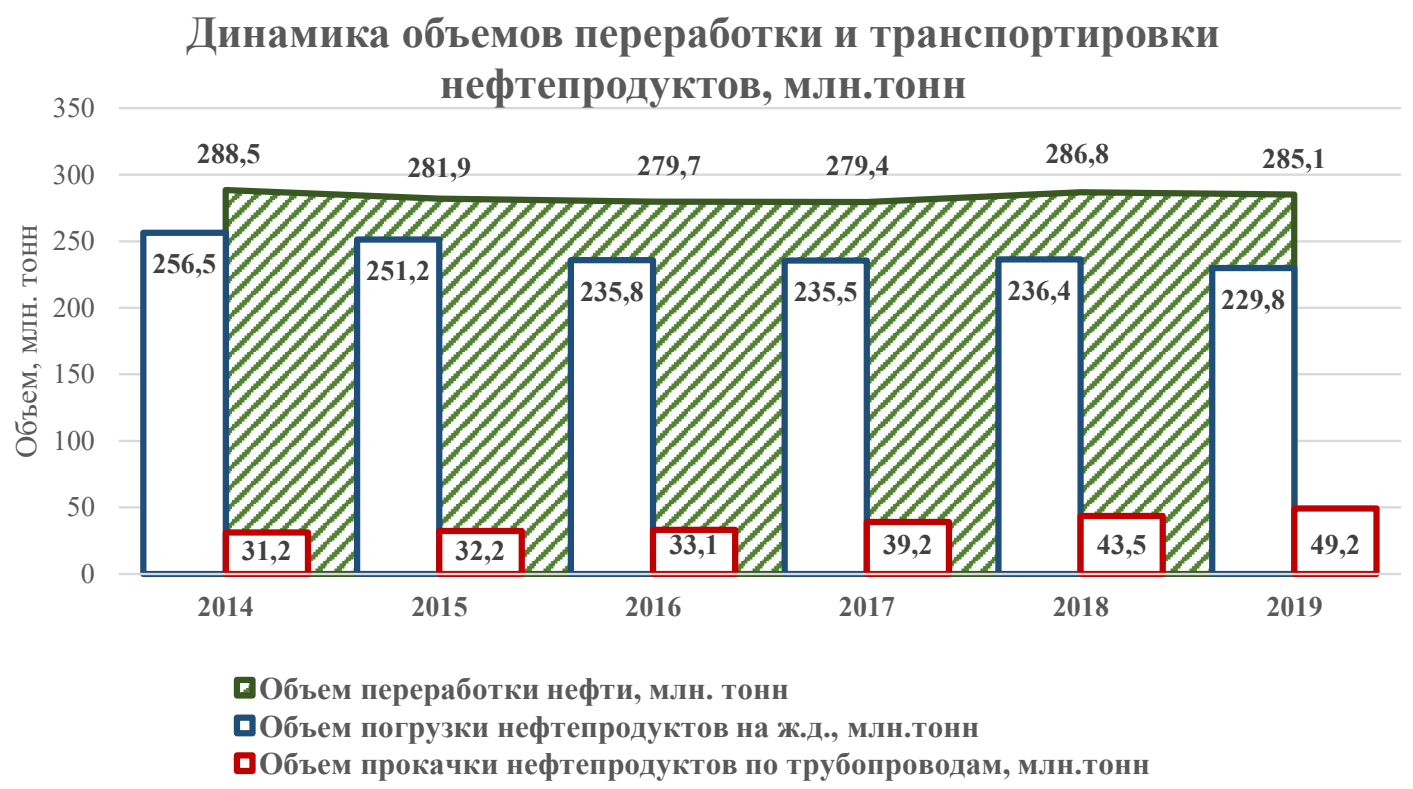

Рисунок 3. Динамика объемов переработки и транспортировки нефтепродуктов [2] 


\section{Прогноз объемов переработки и транспортировки нефтепродуктов, млн. тонн}

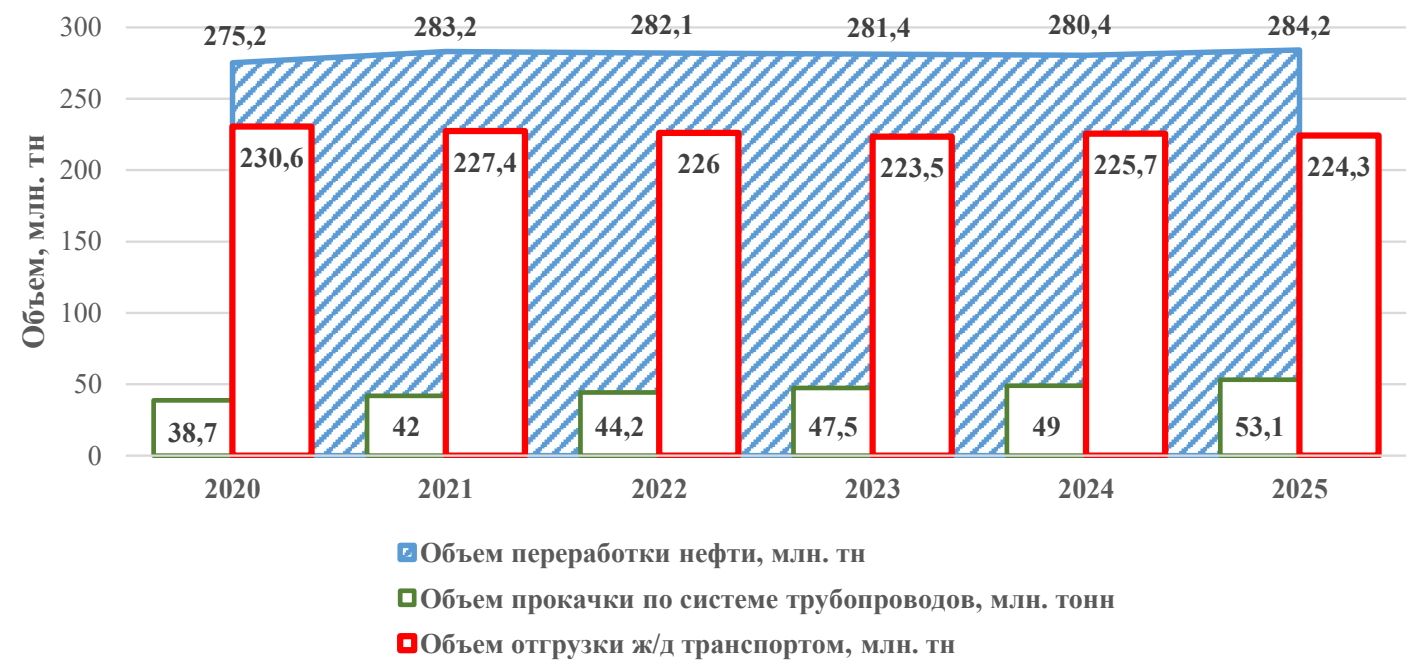

Рисунок 4. Прогноз объемов переработки и транспортировки нефтепродуктов

- Сбытовая политика основных нефтеперерабатывающих предприятий требует большей гибкости с точки зрения объемов и географии поставок, которая не реализуема при массовом переходе на трубопроводный транспорт.

Обозначенные выше факторы, а также объем переработки нефти и технологическая специфика функционирования НПЗ (остановка или задержка отгрузки на несколько суток приводят к «затовариванию» завода и необходимости постановки предприятия на режим рециркуляции), требующая соблюдения ритмичности при вывозе готовой продукции, позволяют с уверенностью сделать вывод, что железнодорожный транспорт является практически безальтернативным.

Однако, принимая во внимание влияние заключенных в конце апреля 2020 года межправительственных соглашений о снижении уровня добычи нефти (в формате ОПЕК+) на отрасль, а, с учетом последствий большого налогового маневра, в первую очередь на снижение объема переработки нефтепродуктов относительно текущего уровня, в условиях сокращения грузовой базы, в совокупности с планами ПАО «Транснефть» по увеличению прокачки на имеющихся нефтепродуктопроводах, прогнозируется усиление межвидовой конкуренции и дальнейшее снижение доли железнодорожного транспорта в общей структуре отгрузки (по прогнозной оценка на 5-6 млн. тонн в год или 3-4\% относительно текущего уровня).
Расчет индекса затрат на содержание подвижного состава.

На ослабление текущих позиций железнодорожного транспорта на рынке также оказало существенное влияние увеличение эксплуатационных затрат компаний-операторов железнодорожных вагонов. Индекс затрат на содержание подвижного состава с 2017 по 2019 годы увеличился более чем на 70\% [2].

Значение индекса рассчитывается на основании данных о стоимости комплектующих вагона (колесные пары, крупные литые элементы рамы вагона) и ценах проведения плановых и текущих ремонтов на крупнейших вагоноремонтных предприятиях.

Наибольшее изменение за анализируемой период произошло по стоимости цельнокатаных колесных пар (+60 тыс.руб или 53\%). Основными причинами столь колоссального роста эксплуатационных затрат являются дефицит комплектующих для ремонта вагонов, связанное с этим увеличение среднего времени ремонта вагонов и инфляция издержек производителей запасных частей.

В результате указанных обстоятельств затраты на содержание и обслуживание цистерны составляют до половины суточной ставки аренды вагона. Рост ставки аренды с 2016 года составил порядка 500 рублей [8]. 
Таблиц̧а 1. Индекс затрат на содержание подвижного состава [2]

\begin{tabular}{|l|c|c|c|c|c|}
\hline \multicolumn{1}{|c|}{ Показатель } & $\mathbf{2 0 1 7}$ & $\mathbf{2 0 1 8}$ & $\mathbf{2 0 1 9}$ & \multicolumn{2}{c|}{$\Delta \mathbf{1 9 - 1 7}$} \\
\hline Стоимость колесной пары, тыс.руб. & $85-95$ & $105-135$ & $135-145$ & $50-60$ & $53 \%$ \\
\hline Стоимость крупного вагонного литья, тыс.руб. & $55-65$ & $65-70$ & $65-80$ & $10-15$ & $18 \%$ \\
\hline Стоимость проведения деповского ремонта, тыс.руб. & $72-75$ & $77-80$ & $82-84$ & $9-10$ & $12 \%$ \\
\hline Стоимость проведения капитального ремонта, тыс.руб. & $110-120$ & $130-135$ & $148-155$ & $35-38$ & $29 \%$ \\
\hline Стоимость ТОР, тыс.руб. & $20-22$ & $23-25$ & $25-28$ & $5-6$ & $27 \%$ \\
\hline Индекс затрат на содержание п/с, руб/сут. & $\mathbf{4 6 5}$ & $\mathbf{5 3 5}$ & $\mathbf{7 9 6}$ & $\mathbf{3 3 1}$ & $\mathbf{7 1 \%}$ \\
\hline
\end{tabular}

\section{Стоимость аренды подвижного состава, руб/ваг/сут}

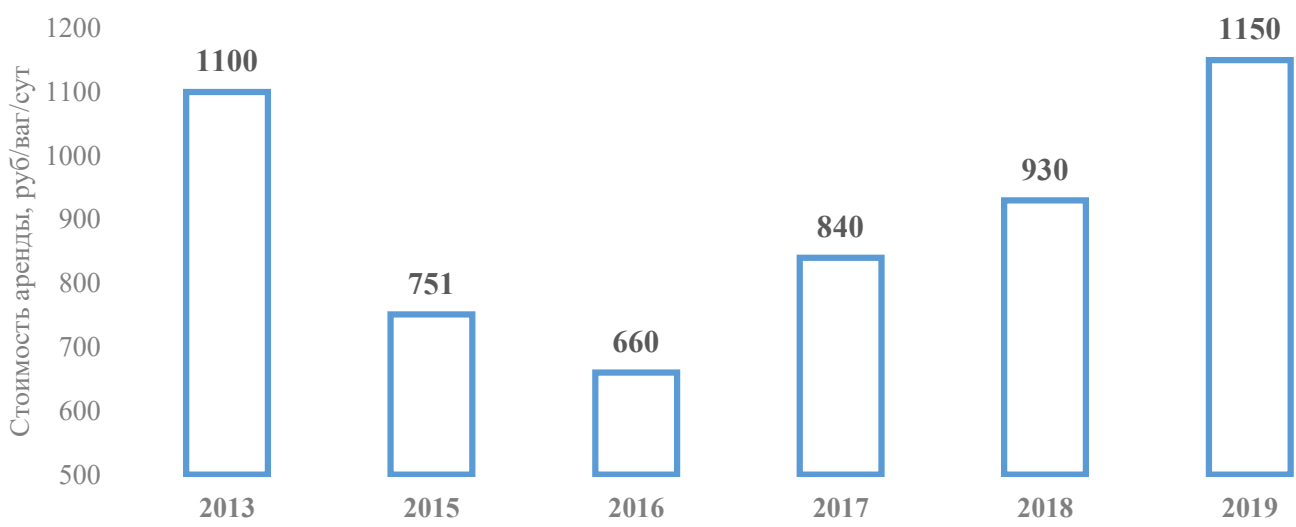

Рисунок 5. Стоимость аренды подвижного состава [8]

Помимо стоимости затрат на содержание подвижного состава на уровень ставок аренды и в конечном итоге стоимости услуг операторских компаний оказал локальный дефицит подвижного состава, вызванный в свою очередь следующими причинами:

- Запрет на продление сроков эксплуатации железнодорожных вагонов цистерн с 2016 года;

- Замедление скорости оборота вагонов на сети железных дорог.

В результате введения запрета количество железнодорожных вагонов-цистерн ежегодно сокращается на 3-5 тысяч единиц, которые подлежат списанию. Таким образом, сложившийся в 2013-2014 годах профицит подвижного состава был полностью нивелирован. Производство нового парка при этом за анализируемый период практически не заказывалось (с 2017 года построено порядка 1000 цистерн).

Причиной дефицита и увеличения ресурсоемкости перевозочного процесса также стало замедление движения на сети. Средний оборот грузового вагона за последние 5 лет увеличился более чем на 3 суток (+30\%) [7].

Увеличение оборота вагонов (по данным Совета операторов железнодорожного транспорта) произошло вследствие превышения нормативного времени простоя вагонов на станциях назначения (средний фактических срок ожидания выгрузки составляет от 3 до 5 суток), что вызвано несогласованностью действий отправителей и грузополучателей. Немаловажную роль сыграла также ограниченность инфраструктуры и сложности с движением в направлении портов Дальнего Востока (куда устремлены основные грузопотоки угля с Кузбасского региона) [6].

Обозначенные выше факторы привели к локальному дефициту подвижного состава и увеличению ресурсоемкости перевозочного процесса, что в совокупности с удорожанием эксплуатационных затрат на содержание парка, оказало непосредственное влияние на уровень стоимости услуг операторских компаний. 


\section{Средний срок оборота вагона, сут}
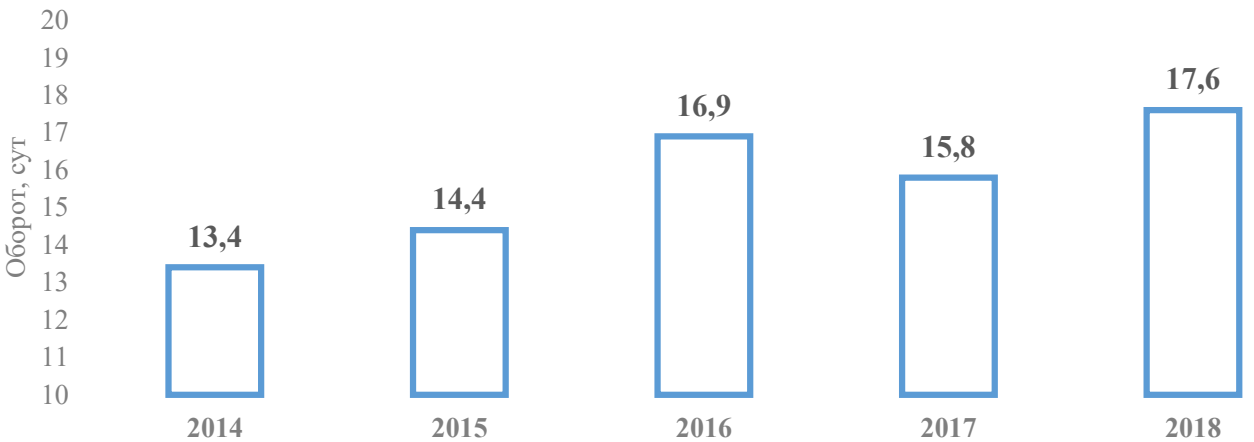

Рисунок 6. Средний срок оборота вагона [7]

Анализ влияния кризисных явлений на трансформацию модели рынка.

Текущий уровень стоимости услуг операторских компаний, соответствует уровню докризисного 2013 года, когда цена на нефть достигала 110-115 долларов США за баррель, а транспортная составляющая в цене отгружаемых нефтепродуктов не играла значительной роли и была несущественной для конечного потребителя. Вместе с тем, в условиях сложившейся экономической ситуации в стране и мире (падение спроса и обвал цен на энергоносители) величина транспортной составляющей в некоторых случаях составляет до 70\% стоимости отпускаемой на НПЗ продукции, в результате чего железнодорожный транспорт становится неконкурентоспособным на отдельных направлениях или расстояниях перевозки.

Тем не менее, учитывая объективное отсутствие полноценной альтернативы железнодорожному транспорту на основных направлениях транспортировки, а также технологически обусловленную зависимость нефтепереработки от ритмичной отгрузки готовой продукции, ком- пании операторы в желании компенсировать выпадение объемов на конкурентных направлениях и галопирующий рост затрат, фактически диктует повышенный уровень цен.

В результате указанной ситуации на рынке прослеживаются тенденция к консолидации парка в целях удержания позиций и сохранения «повышенной» доходности перевозок на направлениях, уровень конкуренции альтернативных видов транспорта на которых незначителен или вовсе отсутствует [4].

На рынке предоставления подвижного состава в сегменте перевозок нефтеналивных грузов доминирует 6-7 крупных операторов, числе которых: ООО «Трансойл», ООО «БалтТрансСервис», АО «Нефтетранссервис», ООО «Совфрахт», $\mathrm{AO}$ «ФГК» и $\mathrm{AO}$ «ПГК».

На долю приведенных в таблице 2 компаний приходится порядка 70\% всего объема перевозок нефтепродуктов производства Российской Федерации. Чуть более $15 \%$ рынка приходится на долю кэптиных операторов - дочерних структур вертикально интегрированных нефтяных компаний, в их число входят: АО «РН-Транс»,

Таблица 2. Крупнейшие собственники железнодорожных цистерн в РФ [9]

\begin{tabular}{|c|c|c|}
\hline Компания-оператор & Парк в управлении, ед. & $\begin{array}{c}\text { Доля рынка по объему } \\
\text { перевозки, \% }\end{array}$ \\
\hline ООО «Трансойл» & 49634 & 30,01 \\
\hline ОО «Нефтетрансервис» & 35467 & 9,42 \\
\hline ООО «Рейлго» & 27803 & 10,27 \\
\hline АО «ПГК» & 16753 & 6,61 \\
\hline ООО «Балттранссервис» & 13678 & 9,70 \\
\hline ООО «Совфрахт» & 11310 & 3,70 \\
\hline АО «ФГК» & 7453 & 2,20 \\
\hline Итого & $\mathbf{1 6 2 0 9 8}$ & $\mathbf{7 1 , 9 1}$ \\
\hline
\end{tabular}


OОО «Газпромтранс», АО «Лукойл-транс» и АО «Сибур-Транс». Оставшиеся 15\% рынка приходится на маленькие независимые операторские и лизинговые компании (свыше 100 представителей).

Указанная структура рынка с небольшими изменениями сохраняется с начала 2018 года, когда небольшие игроки рынка стали объединятся с в связи с необходимостью конкурировать с более крупными компаниями за право организовывать поставки нефтепродуктов не только с нефтебаз и наливных пунктов, но и с нефтеперерабатывающих заводов.

Наиболее ярким примером является образование ООО «Рейлго» в следствие слияния ООО «ИСР», обслуживающего небольшие наливные пункты и нефтебазы и ООО «ОТЭКО», сдававшего парк в аренду. Объединенная структура вошла в список крупнейших операторов на рынке и с начала 2019 года стала одним из операторов Орского, Антипинского и Марийского НПЗ (совокупная грузовая база более 10 млн. тонн нефтепродуктов в год).

Таким образом, компания обеспечила себя стабильной грузовой базой на среднесрочную перспективу и существенно расширила географию присутствия, что способствует выстраиванию наиболее оптимальных логистических схем и сокращению непроизводительного порожнего пробега вагонов.

Помимо консолидации мелких игроков, с рынка уходят и лидеры, так компания АО «ПГК» анонсировала продажу всех нефтебензиновых цистерн и ухода из данного сегмента перевозок, сконцентрировавшись на оперировании полувагонами.

Указанные обстоятельства свидетельствуют о том, что рынок предоставления железнодорожного подвижного состава в сегменте нефтеналивных грузов за последние несколько лет сменил вектор развития, если раньше (до 2018 года) рынок тяготел к развитию конкуренции и из рынка монополистической конкуренции (текущей рыночной структуры) постепенно стремился к модели совершенной конкуренции, то в настоящее время, под влиянием описанных факторов, можно наблюдать его постепенную трансформацию в олигополию.

В сложившихся условиях только крупные ресурсовладельцы (государственные вертикально интегрированные нефтяные компании) могут диктовать условия на рынке и существенно вли- ять на стоимость услуг. Наиболее показательной является модель компании «Роснефть» (крупнейший ресурсовладелец на рынке), суть которой заключается в наличие нескольких операторов подвижного состава на одной площадке зарождения грузопотоков, выбранных посредством конкурентных торгов. В результате чего, в борьбе за крупнейшие площадки погрузки нефтепродуктов собственники подвижного состава вынуждены предлагать ценовые условия, зачастую едва позволяющие балансировать на грани рентабельности. На подобных условиях могут работать только крупные игроки рынка, имеющие широкую географию присутствия и возможность выстроить оптимальную логистику.

Данная ситуация приводит к яркому проявлению второй тенденции на рынке - увеличение стоимости транспортировки на неконкурентных направлениях.

К примеру, стоимость транспортировки нефтепродуктов из Западно-Сибирского региона в порты Дальнего Востока на 35-40\% выше стоимости транспортировки в порты СевероЗапада в расчете на 1 тонну перевозимого груза. Данная неравномерность обусловлена тем, что в Северо-Западный регион осуществляются регулярные массовые поставки нефтепродуктов производства крупных НПЗ, которые способны оказывать влияние на ценовую политику операторов и требовать предоставления специальных условий, в то время как, в порты Дальнего Востока осуществляются нерегулярные поставки в адрес небольших трейдеров. Кроме того, данное направление затруднено с точки зрения эксплуатационной остановки на сети и отсутствия возможности оптимизации логистики. В этой связи, компании операторы на подобных направлениях устанавливают уровень цены, покрывающий описанные издержки, а также компенсирующий недополученную прибыль при перевозках первого типа. В результате чего, стоимость транспортировки составляет до 70\% стоимости конечного продукта.

В завершение анализа текущего состояния рынка транспортировки нефтепродуктов необходимо отметить наметившуюся тенденцию сокращения платежеспособности спроса со стороны заказчиков транспортных услуг.

Так, отпускная стоимость основных продуктов нефтепереработки на российских заводах (бензин, дизельное топливо и мазут), формирующих порядка 65-70\% всей грузовой базы в 


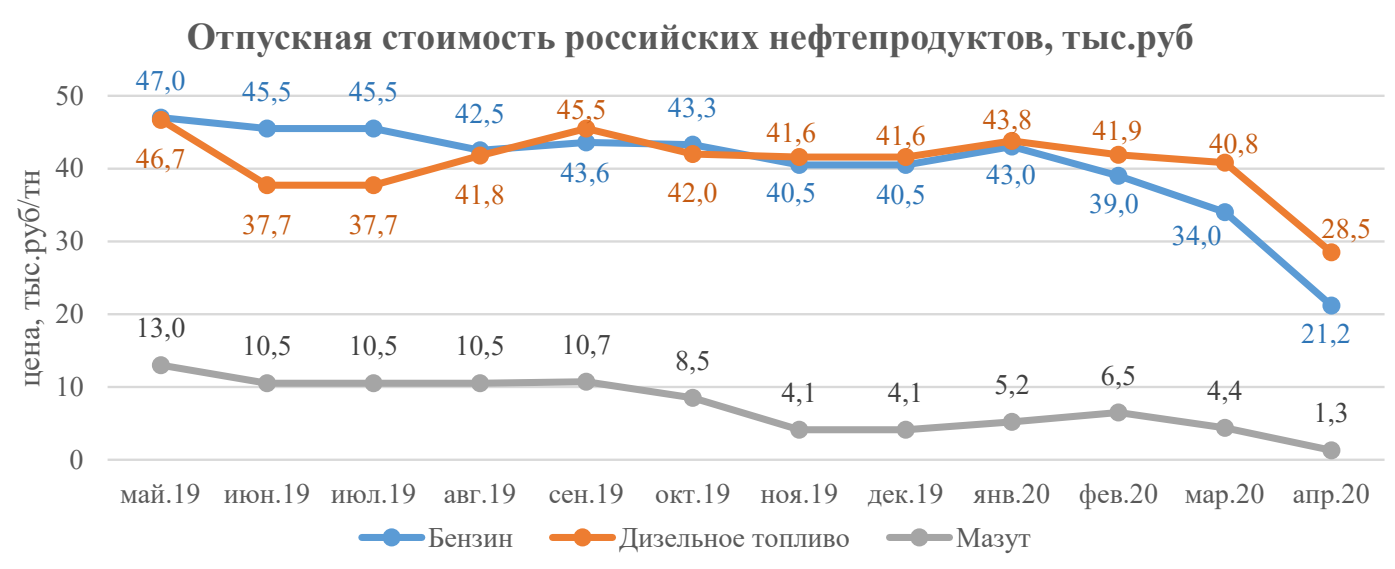

Рисунок 7. Отпускная цена российских нефтепродуктов [2]

данном сегменте рынка по состоянию на апрель 2020 года снизилась относительно аналогичного периода прошлого года на 60-90\%. Столь существенное падение цен на нефтепродукты в начале второго квартала 2020 года обусловлено в первую очень спадом экономической активности и спроса на энергоносители в условиях карантинных ограничений (пандемия COVID-19), а также провал сделки ОПЕК+ и обвал цен на нефть. По предварительным оценкам полное восстановление рынка произойдет не ранее января 2021 года, в связи с чем потребность в оптимизации транспортных затрат усиливается.

\section{Заключение.}

Проведенный анализ позволил систематизировать факторы, влияющие на изменения рынка отгрузки нефтепродуктов на железнодорожный транспорт. По итогам оценки влияния рыночных тенденций на основные объемные показатели отрасли уточнен прогноз объемов переработки и объемов перевозки нефтеналивных грузов различными видами транспорта.

Анализ предпосылок и причин ослабления текущих позиций железнодорожного транспорта на рынке показал, что существенным образом на снижение конкурентоспособности повлияло увеличение эксплуатационных затрат компаний-операторов железнодорожных вагонов, многократно превышающее уровень инфляции и рост стоимости логистических услуг. Расчетный индекс затрат на содержание подвижного состава за период с 2017 по 2019 год вырос более чем на $70 \%$.

Факторная оценка текущего состояния рынка и анализ изменения его структуры позволили сделать вывод о тенденции трансформации конкурентной модели, к которой рынок стремился после реформирования, в рынок олигополии, что существенно меняет бизнес-модели большинства операторов.

\section{Направление дальнейших исследований.}

В сложившейся ситуации, возникают следующие предпосылки к оптимизации затрат на оказание транспортно-логистического сервиса и повышению эффективности деятельности компаний операторов железнодорожного транспорта:

- Рост затрат на содержание подвижного состава;

- Увеличение ресурсоемкости перевозочного процесса;

- Необходимость удержания объемов на железнодорожном транспорте в условиях усиливающейся межвидовой конкуренции;

- Консолидация парка в руках крупных игроков и трансформация рынка;

- Снижение уровня цен и спроса на основные нефтепродукты;

- Ценовое давление со стороны крупных ресурсовладельцев.

В качестве одного из вариантов решения данных задач предлагается рассмотреть реализацию проекта внедрения параметрической модели ценообразования, основанной на учете факторов, влияющих на эффективность использования вагона, и позволяющей справедливо распределить затраты на организацию перевозочного процесса между его участниками при снижении стоимости услуг для конечного потребителя. 


\section{Библиографический список}

1. Александрова С.И. Прогрессивные методы управления затратами и пути их применения в российской практике / С.И.Александрова // Символ науки. - 2015.- № 4.- С. 56-59.

2. Аникеева-Науменко Л. О. Методы повышения эффективности использования вагонов грузового парка на железнодорожном транспорте: дис. ... канд. техн. наук: - М.: МИИТ, 2014.-190 с.

3. АРГУС - Нефтетранспорт: информационно-аналитическое издание / под ред. О.А. Кирсанова.- M.: Argus media, 2019. - 85 c.

4. Егоров Ю.В. Уровень железнодорожных тарифов как фактор конкурентоспособности железнодорожного транспорта /Ю.В. Егоров // Развитие экономической науки на транспорте: устойчивость развития железнодорожного транспорта: сборник докладов IV Международной научно-практической конференции / под ред. Проф. Н.А. Журавлевой.-Санкт-Петербург, 2020 г.

5. Житинев П.Ю. Формирование предпосылок к повышению эффективности использования железнодорожного подвижного состава при транспортировке нефти и нефтепродуктов /П.Ю. Житинев// Актуальные вопросы экономики транспорта высоких скоростей: сборник работ международной научно-практической конференции / под ред. Проф. Н.А. Журавлевой.-Санкт-Петербург, 2020 г.

6. Журавлева Н. А. Методология исследования цифровой трансформации в условиях дестабилизации бизнесмоделей транспортных организаций. / Н. А. Журавлева // Методология развития экономики, промышленности и сферы услуг в условиях цифровизации / под ред. Проф. А. В. Бабкина.-Санкт-Петербург, 2018 г.

7. Михайлов П.А. Актуальные проблемы рынка железнодорожных грузовых перевозок / П.А. Михайлов// Развитие экономической науки на транспорте: проблема оптимизации бизнеса: сборник научных статей V Международной научно-практической конференции / под ред. проф. Н.А.Журавлевой.- СанктПетербург, 13-14 октября 2016 г.-С. 307-3014.

8. Никифорова Г.И. Исследование проблем деятельности операторских компаний в управлении вагонным парком / Г. И.Никифорова // Профессиональное образование, наука и инновации в XXI веке: сб. трудов XII С.-Петерб. конгресса.-СПб.: ПГУПС, 2018.- С. 172-173.

9. Руденко E. В. Тарифообразующие факторы на рынке железнодорожных перевозок нефти и нефтеналивных грузов /Е.В. Руденко, М.А. Лякина // Актуальные вопросы экономики транспорта высоких скоростей: сборник работ международной научно-практической конференции / под ред. Проф. Н.А. Журавлевой.- СанктПетербург, 2020 г.

10. Транспорт России. Официальный печатный орган Министерства транспорта РФ. [Электронный ресурс].2019 - Режим доступа: http://transportrussia.ru/item/5144-berut-vagon-v-oborot.html 